\title{
Modification by natural sources to reduce immuno-reactivity of milk proteins
}

\author{
Recep AKKAYA ${ }^{1 *}$ (D), Birnur AKKAYA ${ }^{2}$ (D), Serap ÇETINKAYA ${ }^{2}$ (i) \\ ${ }^{1}$ Faculty of Medicine, Department of Biophysics, Cumhuriyet University, Sivas / Turkey \\ ${ }^{2}$ Department of Molecular Biology and Genetics, Cumhuriyet University, Sivas / Turkey
}

\begin{abstract}
The main aim of the current study was to reduce the IgE-binding capacity of cow's milk through its chemical modification by natural source treatment. The presence of children allergic responses to cow's milk has become a growing concern in the world. A possible approach to reduce protein allergen is to block IgE-binding epitopes of protein allergen by various methods. One of them is protein glycation. We wanted to examine effect of some additives especially lemon juices on milk protein modification by using electrophoresis and 2D gel electrophoresis. As a result of this study lemon juice (ascorbic acid) enhanced glycation of milk proteins.
\end{abstract}

\section{Article info \\ History:}

Received:02.12.2019

Accepted:12.03.2020

Keywords:

Ascorbic acid,

cow milk allergy,

2-DE,

glycation,

IgE.

\section{Introduction}

The allergy to cow's milk proteins (CMPA) occurs after the ingestion of cow's milk and is described by the immune mechanisms. Immune reaction can be IgEmediated (Type 1), non-IgE-mediated (cell-mediated) or mixed-type (IgE-mediated or non-IgE-mediated). Cow's milk contain a lot of proteins and all of them are poteintial allergen and they act as an antigen [1]. The most known allergenic proteins are $\alpha$-lactalbumin $(\alpha$ LA), $\beta$-lactoglobulin ( $\beta$-LG) and caseins. Modifying these proteins to reduce milk protein allergenicity is chemical modification by acetylation, succinylation, citrinilation, decitrinilation, phosphorylation and methylation. Heat treatment, irradiation, glycation reaction, high pressure, enzymatic hydrolysis and lactic acid fermentation are currently useful way to reduce the allergenicity. The most frequently studied chemical modification of milk proteins is the Maillard reaction, which is a nonenzymatic glycation in which the carbonyl group of the reducing sugars (primarily lactose) reacts with the carbonyl group [2]. A reducing carbohydrate or ascorbic acid can react with amino acids, peptides and proteins and this reaction is known as Maillard reaction.

The formed protein carbonyls can reduce the nutritional value of the milk by irreversible inhibition of the essential amino acids which reduce protein digestibility. These modifications can also change protein structure, cause to aggregation, and initiate or inhibit allergic reactions by forming or masking epitopes [3].

In this work we aimed to prevent and eliminate cow's milk allergy by using natural sources on milk protein modification. We selected natural sources because they was harmless to the body and the most abundant natural sources including yoghurt, vinegar, salt, lemon juices and protease from Candida kefyr 41 PSB [4]. were used. It is stable at literature that ascorbic acid cause to glycation of carbohydrate. Lemon juice can change the $\mathrm{pH}$ of milk and also can cause to non enzymatic glycation. First of all, we tried to add different additives and we continiue with the most suitable additive, lemon juices and characterized by electrophoresis. For this purpose we used whole milk from cows.

\section{Materials and Methods}

\subsection{Materials}

Whole cow milk has been purchased from the local farmers in Sivas/Türkiye. Lemon, yoghurt, vinegar and salt have been purchased from market. All of the PAGE and SDS-PAGE chemicals are high quality (Sigma Aldrich).

\subsection{Protein preparation}


Milk proteins were precipitated by adding two volumes of $95 \%$ cold ethanol and incubated overnight at $-20^{\circ} \mathrm{C}$. Protein precipitate was centrifugated and dried at room temperature (RT). The organic and aqueous phases were discarded after centrifugation $(10 \mathrm{~min}, 10,000 \mathrm{~g}$, $4{ }^{\circ} \mathrm{C}$ ), the remaining protein pellets were immediately dried under vacuum, and dissolved in phosphate buffer (50 Mm pH 7.0). Protein concentration was determined by spectrophotometry at $280 \mathrm{~nm}$.

\subsection{PAGE, SDS-PAGE AND 2D electrophoresis (Two dimensional gel electrophoresis)}

Milk proteins were assayed by sodium dodecyl sulphate-polyacrylamide gel electrophoresis using $12 \%$ seperating gel; 5\% stacking gels were stained with $0.25 \%$ Coomassie Brillant R 250 in acetic acidmethanol-water $(1: 5: 5, \mathrm{v} / \mathrm{v} / \mathrm{v})$ and destained in ethanolacetic acid-water $(1: 4: 6 \mathrm{v} / \mathrm{v} / \mathrm{v})$.

Milk protein samples were analyzed by 2-DE experiments which performed at Kocaeli University DEKART proteomics laboratory [5]. For the first separation, $80 \mu \mathrm{g}$ of milk protein were loaded onto $\mathrm{pH}$ gradient strips (immobilized $\mathrm{pH}$ gradient, IPG) ( $\mathrm{pH} 3-$ $10,17 \mathrm{~cm}$; BioRad, USA) by rehydrated. Isoelectric focusing separation based on isoelectric points was performed by using Protean isoelectric focusing cell (Bio-Rad, USA). The strips were run through a stepwise incremental voltage program $(250 \mathrm{~V}$ for 20 min (linear), $4000 \mathrm{~V}$ for $2 \mathrm{hr}$ (linear) and $10000 \mathrm{~V} / \mathrm{hr}$ (rapid). The strips were then equilibrated in equilibration buffer-I (6M urea, 2\% SDS, $0.375 \mathrm{M}$ Tris- $\mathrm{HCl} \mathrm{pH} \mathrm{8.8,} \mathrm{20 \%} \mathrm{glycerol} \mathrm{and} \mathrm{2 \%} \mathrm{DTT)} \mathrm{and} \mathrm{then}$ buffer-II which is the same buffer without DTT but with iodoacetamide (2.5\%). After isoelectric focusing, the strips were added to SDS-PAGE using $12 \%$ inhome made gels and separated according to their molecular wights. Experiments are triplicate. Gel was fixed during 6 hours in fixation buffer (40\% methanol, $10 \%$ acetic acid). After fixation the gel was put in by SYPRO Rubby (Bio-Rad, US) and spots were visualized.

\section{Results and Discussion}

\subsection{Protein preparation}

After preparation of cow milk protein isolates, all of the treated protein isolates were runned at PAGE and SDS-PAGE. Figure 1 shows the PAGE and SDSPAGE gels of cow milk proteins which are treated by natural sources. Number 8 line showed decreased band intensity. The proteins were treated by lemon juice $(1000 \mu 1)$. These are an indication that lemon juice could alter structure of proteins. That is why we continued with lemon juice treated proteins for further investigations. After this selection we measured the $\mathrm{pH}$ values of lemon juice treated samples. As our aim was selection of structually modified protein but not so much, we selected the less modified $\mathrm{pH}$ value among the different concentrations of protein samples. That is why we decided to continue with milk (1000 $\mu \mathrm{l})+$ lemon juice $(5 \mu \mathrm{l})$ sample (Table 1$)$.

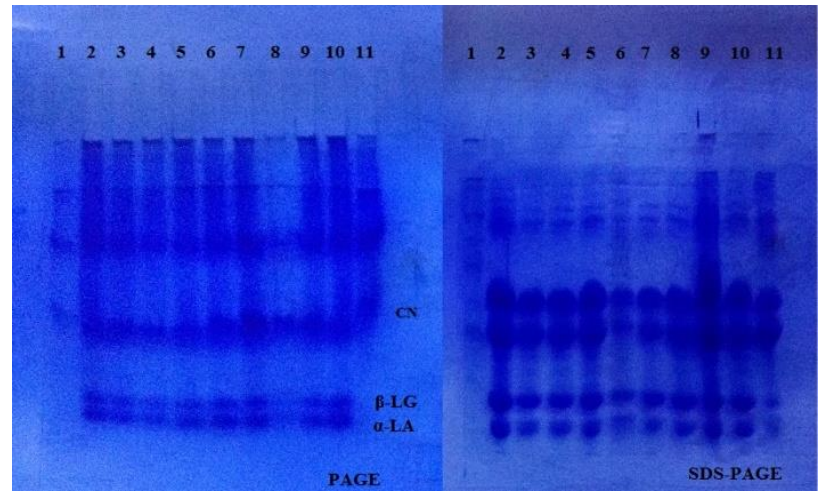

Figure 1. PAGE and SDS-PAGE analysis of treated cow's milk samples. \{1-casein, 2-milkmarker (1/5), 3-salt + milk $(20 \mathrm{mg} / \mathrm{mL}), 4$ - protease + milk $(0.5 \mathrm{mg} / \mathrm{mL}), 5$ - vinegar + milk $(5 \mu \mathrm{L}), 6$ - lemon juice + milk $(5 \mu \mathrm{L}), 7$ - lemon juice + milk $(200 \mu \mathrm{L}), 8$ - lemon juice + milk $(1000 \mu \mathrm{L}), 9$ - yoghurt + milk $(200 \mu \mathrm{L}), 10$ - milk marker $(1 / 5), 11-$ casein $\}$

Table 1. Physical properties of milk and modified milk

\begin{tabular}{|l|l|}
\hline Sample & pH \\
\hline Milk $(1000 \mu \mathrm{l})+$ lemon juice $(1000 \mu \mathrm{l})$ & 2,81 \\
\hline Milk $(750 \mu \mathrm{l})+$ lemon juice $(1000 \mu \mathrm{l})$ & 3,26 \\
\hline Milk $(500 \mu \mathrm{l})+$ lemon juice $(1000 \mu \mathrm{l})$ & 3,49 \\
\hline Milk $(250 \mu \mathrm{l})+$ lemon juice $(1000 \mu \mathrm{l})$ & 3,96 \\
\hline Milk $(200 \mu \mathrm{l})+$ lemon juice $(1000 \mu \mathrm{l})$ & 4,67 \\
\hline Milk $(1000 \mu \mathrm{l})+$ lemon juice $(100 \mu \mathrm{l})$ & 4,72 \\
\hline Milk $(1000 \mu \mathrm{l})+$ lemon juice $(50 \mu \mathrm{l})$ & 5,58 \\
\hline Milk $(1000 \mu \mathrm{l})+$ lemon juice $(20 \mu \mathrm{l})$ & 5,84 \\
\hline Milk $(1000 \mu \mathrm{l})+$ lemon juice $(10 \mu \mathrm{l})$ & 6,44 \\
\hline Milk $(1000 \mu \mathrm{l})+$ lemon juice $(5 \mu \mathrm{l})$ & 6,35 \\
\hline
\end{tabular}

Figure 2 shows the electromagnetic spectrum. Electronic absorption spectra of proteins are primarily characterized over the ultraviolet region (185-320 nm) of the electromagnetic spectrum [6]. The protein sample was dissolved in deionized water and the absorption spectra (185-320 nm) were scanned. Pure deionized water was kept as blank control for the measurements. This measurements were done for 1 $\mathrm{mg} / \mathrm{ml}$ milk samples. The spectrum were the same, that means the protein structure was not modified. Without depletion of protein a little bit modification of protein 
is important for decreasing allergenicity. By this way milk will keep the protein as nutritional factor but at the same time this modification cause to decrease of allergenicity.

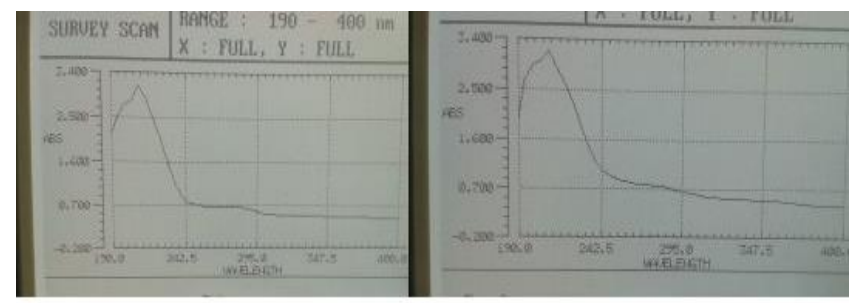
milk+lemon juice $(5 \mu \mathrm{l}) \quad$ milk

Figure 2. UV region scanning $(185-320 \mathrm{~nm})$ of milk and milk+lemon juice $(5 \mu \mathrm{l})$

\subsection{Two dimensional gel electrophoresis (2 DE)}

According to $2 \mathrm{DE}$ results (Figure 3), there are depletion of $\mathrm{CN}$ (casein fractions) after lemon juice treatment. Similar results were found by Hsieh and Pan [7]. which treated milk with microbial transglutaminase. $\mathrm{CN}$ were effected more than other milk proteins (Figure 3). Milk protein included $80 \%$ of caseins and $20 \%$ whey proteins [8]. Because of glycosylation reactions milk proteins are present in different forms and different levels of degradation. Glycolisation could be change the properties of protein such as pI or molecular weight [8].

L-ascorbic acid (Vitamin C) which reduce the carbohydrate can covalently bind to amino acids, peptides or proteins. This reaction is known as Maillard reactions [9].

Reduction of milk protein allergenicity by the Maillard reaction is performed in detailed procedure $[10,11]$.

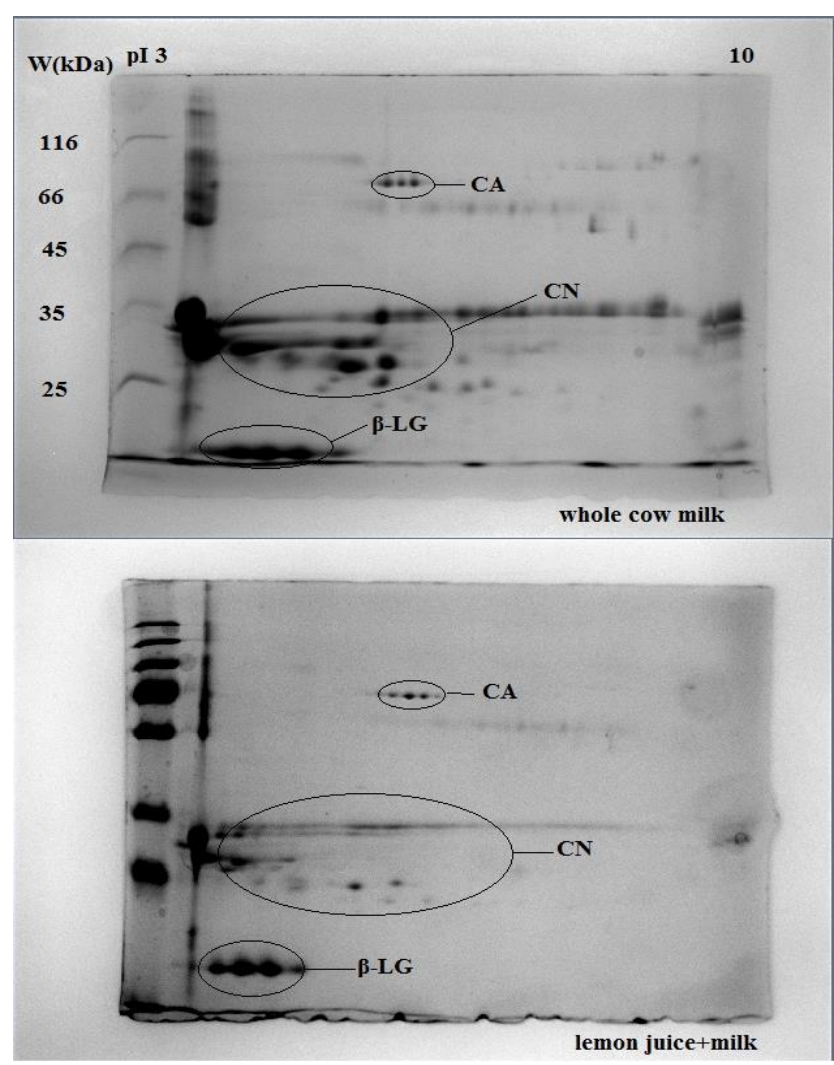

Figure 3. Two dimensional gel electrophoresis of milk and lemon juice + milk $(5 \mu \mathrm{l})$ proteins at $37{ }^{\circ} \mathrm{C}$ for $1 \mathrm{~h}$. Comparison of abundance levels of albumin, caseins, $\beta$ lactoglobulin, in normal and treated milk. Circles indicated albumin, caseins and $\beta$-lactoglobulin ( $\beta$-LG).

\section{Conclusions}

In the current study, the effects of natural source treatment on cow milk proteins were investigated by 2D PAGE analyses and the treated sample is a potential candidate to reduce the allergenic reactivity investigations at the future. We aimed protein modification without depletion of protein from milk. The analysis of the protein sample showed that the treated sample could be used as potential candidate for further analyses by ant-allergenic tests.

The interactions between milk proteins and some components of the natural sources could seem to play a role in the possible reduction of allergenicity. Further studies will be employed in vitro studies and in cow milk allergic patients.

\section{Acknowledgment}

The authors thank the institution for using the facilities of the Cumhuriyet University. 


\section{Conflicts of interest}

The authors state that did not have conflict of interests.

\section{References}

[1] Martorell-Aragonés A., Echeverría-Zudaire L., Alonso-Lebrero E., Boné-Calvo J., MartínMuñoz MF., Nevot-Falcó S., Piquer-Gibert M., Valdesoiro-Navarrete L., Position document: IgE-mediated cow's milk allergy, Allergologia et Immunopathologia., 43 (2015) 507-526.

[2] Renzone G., Arena S., Scaloni A., Proteomic characterization of intermediate and advanced glycation end-products in commercial milk samples, J Proteomics., 18 (2015) 12-23.

[3] Milkovska-Stamenova S., Mnatsakanyan R., Hoffmann R., Protein carbonylation sites in bovine raw milk and processed milk products, Food Chem., 229 (2017) 417-424.

[4] Yavuz, S., Kocabay S., Çetinkaya S., Akkaya B., Akkaya R., Yenidünya A.F., Bakıcı M.Z., Production, purification and characterization of metalloprotease from Candida kefyr 41 PSB, Int. J.of Biologic. Macromol., 84 (2017)106113.

[5] Akpınar G., Şimşek T., Kasap M., Cantürk N.Z., A Preliminary Study: Comparative Proteomic
Profiling Of Breast Cancer Tissue and Metastatic Axillary Lymph Node, Journal of Breast Health., 9 (2013) 64-68.

[6] Simona L. B., Angelis E.D., Simona B., Rosa P., Francesa M., Elio M.N., Linda M., Modulation of Milk Allergenicity by Baking Milk in Foods: A Proteomic Investigation, Nutrients., 11 (2019) 1536-1550.

[7] Hsieh J. F., and Pan. P. H., Proteomic profiling of microbial transglutaminase-induced polymerization of milk proteins, J. Dairy Sci., 95 (2012) 580-590.

[8] Wang A., Duncan S.E., Knowlton K.F., Ray W.K., Dietrich A.M., Milk protein composition and stability changes affected by iron in water sources, J. Dairy Sci., 99 (2016) 4206-4219.

[9] Troise A. D., Vitiello D., Tsang C., Fiore A., Encapsulation of ascorbic acid promotes the reduction of Maillard reaction products in UHT milk, Food Funct., 7 (2016) 25912601.

[10] Bu G., Luo Y., Chen F., Liu K., Zhu T., Milk processing as a tool to reduce cow's milk allergenicity: a mini-review, Dairy Sci. \& Technol., 93 (2013) 211-223.

[11] Villa, C., Costa J., Beatriz M.P.P., Mafra I., Bovine Milk Allergens: A Comprehensive Review, Comprehensive Reviews in Food Science and Food Safety., 17 (2018) 137-164. 